\title{
POROVNANIE VÝŠKY NÁKLADOV ZA PRÍSTUP NA DOPRAVNÚ INFRAŠTRUKTÚRU V CESTNEJ A ŽELEZNIČNEJ NÁKLADNEJ DOPRAVE NA VYBRANÝCH ÚSEKOCH V PODMIENKACH SLOVENSKEJ REPUBLIKY
}

\section{COMPARING THE COSTS OF ACCESS TO THE TRANSPORT INFRASTRUCTURE ON ROAD AND RAIL FREIGHT TRANSPORT ON SELECTED ROUTES IN THE CONDITIONS OF THE SLOVAK REPUBLIC}

Šimon Senko ${ }^{1}$, , Jozef Gnap ${ }^{1}$

\begin{abstract}
Abstrakt Príspevok sa zaoberá porovnaním nákladov spojených s prístupom na dopravnú siet' v cestnej a železničnej nákladnej doprave na vybraných úsekoch v podmienkach Slovenskej republiky. Analyzuje náklady na vybraných trasách z hl'adiska absolútnej a jednotkovej ceny a porovnáva faktory vplývajúce na tieto náklady.

Klíčová slova dopravná infraštruktúra, náklady, poplatky, faktory, nákladná doprava

Summary The paper deals with the comparison of costs related to access to the transport network in road and rail freight transport on selected sections in the conditions of the Slovak Republic. It analyzes costs on selected routes in terms of absolute and unit prices and compares factors affecting these costs.
\end{abstract}

Keywords transport infrastructure, costs, charges, factors, freight transport

\section{1 ÚVOD}

Spoplatnenie železničnej dopravnej infraštruktúry bolo zavedené aj v Slovenskej republike na základe právnych predpisov EÚ, kvôli ktorým boli zriadené zvláštne vnútroštátne inštitúcie. $Z$ dôvodu liberalizácie trhu. bolo efektívne, aby sa súčasne zaistilo, že úrovne bezpečnosti budú zachované a zvýšené. Tento systém zahŕňa vnútroštátne bezpečnostné orgány (NSA -National Safety Authorities) a regulačné orgány (Zgonc et al., 2019). Úlohou regulačných orgánov je zabezpečit’ spravodlivý a nediskriminačný prístup na železničnú siet' a k železničným službám a overit', či sa náležite uplatňujú zásady poplatkov a pridel'ovania kapacít. Nariadenia predpokladajú koordináciu medzi všetkými zúčastnenými stranami a krajinami najmä v pridel'ovaní cezhraničnej kapacity, časových plánoch investícií, normách infraštruktúry a stanovení poplatkov za prístup na trate (Gnap et al., 2019), (Skrúcaný et al., 2018). Biela kniha, Plán jednotného európskeho dopravného priestoru - Vytvorenie konkurencieschopného dopravného systému efektívne

\footnotetext{
1 Žilinská univerzita v Žiline, Fakulta prevádzky a ekonomiky dopravy a spojov, Katedra cestnej a mestskej dopravy, Univerzitná 8215/1, 01026 Žilina, Slovenská republika

* korespondenční autor, tel.: +421 41513 3524, simon.senko@fpedas.uniza.sk
} 
využívajúceho zdroje určuje víziu aj v oblasti spoplatnenia používania dopravnej infraštruktúry až do roku 2030 a niektoré úlohy smerujú až k roku 2050 (Biela kniha, 2011). Snahou spoplatnenia cestnej infraštruktúry bola aj snaha znížit' externality z cestnej nákladnej dopravy (Huber et al., 2017). V železničnej nákladnej doprave na elektrifikovaných tratiach je prioritou uplatnenie pravidla užívatel' dopravnej infraštruktúry platí za jej používanie (Jost, 2017), (Odolinski, Boysen, 2019). Cena poplatkov za používanie cestnej infraštruktúry by mala regulovat' aj dopyt po jej používaní a nárast emisií a preto sa autor Lee, (2018) snaží vytvorit' matematický model (Lee, 2018). Problematikou kalkulácie nákladov na konkrétne trasy prepravy sa zaoberali autori (Poliak et al., 2018), kde brali do úvahy aj priemerné poplatky za dopravnú cestu v cestnej nákladnej doprave (Poliak et al., 2019).V železničnej nákladnej doprave máme aj v SR úzke miesta, kde kapacity železničných tratí vzhl'adom na vel'ký nárast osobnej dopravy nestačí napr. Dunajská Streda - Bratislava. Preto je vel'mi zaujímavý príspevok autorov (Stopka et al., 2017) ako opatreniami zvýšit' priepustnost' trate (Stopka et al., 2017). Na druhej strane je možné regulovat' dopyt po prístupe na železničnú infraštruktúru výškou poplatkov.

\section{MATERIÁL A METODIKA}

Výpočet nákladov spojených s prístupom na dopravnú siet’ bol realizovaný kalkulátormi jednotlivých manažérov dopravných sietí. Kalkulátor pre cestnú infraštruktúru je dostupný na portáli elektronického systému výberu mýta v Slovenskej republike. Pre cestnú nákladnú dopravu bola vybraté nákladné vozidlo napr. návesová súprava nad 12 ton celkovej hmotnosti s 5 nápravami. Pre toto vozidlo bol následne zohl'adnený aj faktor emisnej kategórie, konkrétne pre emisnú kategóriu 0-II (najvyššia sadzba), emisnú kategóriu V, VI a EEV (najnižšia sadzba) a emisnú kategóriu V, VI a EEV s najvyššou možnou zl'avou 9 \%, ktorá je určená pre vozidlá, ktoré $v$ rámci kalendárneho roku najazdia na spoplatnených úsekoch viac ako 50000 km. Výpočet výšky nákladov pre železničnú infraštruktúru bol realizovaný pomocou aplikácie na výpočet úhrad ako i znížených úhrad, dostupný na webovom sídle manažéra infraštruktúry Železnice Slovenskej republiky (ŽSR). V tomto prípade ako vstupné údaje slúžili jednotlivé trasy na posudzovanej infraštruktúre, pravidelnost' trasy (či je trasa v GVD alebo nie), a možná výška poskytnutej zl'avy manažérom infraštruktúry. Vybrané boli konkrétne dva prípady a to vlak pravidelnej trasy so zlavou pre vlaky Nex a Pn (najnižšia sadzba) a vlak nepravidelnej trasy bez akejkol'vek zl'avy (najvyššia sadzba). Manažér železničnej infraštruktúry taktiež používa diferenciáciu ceny v závislosti od vzdialenosti.

\section{VYHODNOTENIE NÁKLADOV SPOJENÝCH S PRÍSTUPOM NA DOPRAVNÚ INFRAŠTRUKTÚRU}

Na obrázkoch č. 2, 4, 6 a 8 sú znázornené jednotlivé vybrané trasy pre porovnanie nákladov spojených s prístupom na dopravnú siet'. Jednotlivé prepravné relácie boli vybraté na základe reálnych trás ponúkaných železničnými dopravcami, ktoré boli zaradené aj v pláne vlakotvorby pre rok 2019. Trasy cestnej dopravy boli následne určené tak, aby čo najpresnejšie kopírovali trasy železničnej dopravy.

Výpočet bol realizovaný pre vozne typu Habbins, nakol'ko obmedzujúcim faktorom pri výbere vozňov bola celková dĺžka vlakovej súpravy. Ani pri plnom zat’ažení týchto vozňov nie je na vybraných trasách prekročené zvislé zat'aženie trate. 
Tab. 1 Vybrané trasy železničnej dopravy, ich dĺžka, cena, úžitková hmotnost' a prepravný výkon; Zdroj: Autori

\begin{tabular}{|c|c|c|c|c|c|c|c|}
\hline \multirow{2}{*}{ Trasa } & \multirow{2}{*}{$\begin{array}{c}\text { Vzdialenost' } \\
{[\mathrm{km}]}\end{array}$} & \multicolumn{2}{|c|}{ Cena bez DPH } & \multirow{2}{*}{$\begin{array}{c}\text { Jednotková } \\
\text { cena } \\
{[€ / \mathbf{k m}]}\end{array}$} & \multirow{2}{*}{$\begin{array}{c}\text { Úžitková } \\
\text { hmotnost' } \\
\text { celková } \\
\text { [t] }\end{array}$} & \multirow{2}{*}{$\begin{array}{c}\text { Prepravný } \\
\text { výkon } \\
\text { [tkm] }\end{array}$} & \multirow{2}{*}{ Poznámka } \\
\hline & & $\begin{array}{c}\text { Absolútna } \\
{[€]}\end{array}$ & $\begin{array}{c}\text { Jednotková } \\
{[€ / \mathbf{k m}]}\end{array}$ & & & & \\
\hline $\begin{array}{c}\text { KE } \\
\text { nákladná }\end{array}$ & & 388,67 & 0,88 & 0,00055 & & & $\begin{array}{l}\text { pravidelná, } \\
\text { zl'ava pre }\end{array}$ \\
\hline $\begin{array}{c}\text { - BA } \\
\text { východ }\end{array}$ & 444,07 & & & & 1587,5 & 704961,125 & Nex a Pn \\
\hline $\begin{array}{c}\text { severná } \\
\text { trasa }\end{array}$ & & 625,93 & 1,41 & 0,00089 & & & $\begin{array}{c}\text { príležitostná } \\
\text { bez zl'avy }\end{array}$ \\
\hline $\begin{array}{c}\text { BA } \\
\text { východ - } \\
\text { ZV nákl. - }\end{array}$ & 428,72 & 360,64 & 0,84 & 0,00063 & 1333,5 & 571698,12 & $\begin{array}{c}\text { pravidelná, } \\
\text { zl'ava pre } \\
\text { Nex a Pn }\end{array}$ \\
\hline KE nákl. & & 584,75 & 1,36 & 0,00102 & & & $\begin{array}{c}\text { príležitostná } \\
\text { bez zl'avy }\end{array}$ \\
\hline $\begin{array}{c}\text { ZV } \\
\text { východ - } \\
\text { BB - ZA }\end{array}$ & 112,67 & 105,8 & 0,94 & 0,00082 & 1143 & 128781,81 & $\begin{array}{c}\text { pravidelná, } \\
\text { zl'ava pre } \\
\text { Nex a Pn }\end{array}$ \\
\hline Teplička & & 232,56 & 2,06 & 0,00181 & & & $\begin{array}{c}\text { príležitostná } \\
\text { bez zl'avy }\end{array}$ \\
\hline Nit. & & 124,81 & 0,81 & 0,00071 & & & $\begin{array}{c}\text { pravidelná, } \\
\text { zl'ava pre }\end{array}$ \\
\hline Pravno - & 154,09 & & & & 1143 & 176124,87 & Nex a Pn \\
\hline Komárno & & 190,15 & 1,23 & 0,00108 & & & $\begin{array}{c}\text { príležitostná } \\
\text { bez zl'avy }\end{array}$ \\
\hline
\end{tabular}


Tab. 2 Vybrané trasy cestnej dopravy, ich dížka, cena a prepravný výkon; Zdroj: Autori

\begin{tabular}{|c|c|c|c|c|c|c|}
\hline \multirow{2}{*}{ Trasa } & \multirow{2}{*}{$\begin{array}{c}\text { Vzdialenost' } \\
{[\mathrm{km}]}\end{array}$} & \multicolumn{2}{|c|}{ Cena bez DPH } & \multirow{2}{*}{$\begin{array}{c}\text { Jednotková } \\
\text { cena } \\
{[€ / \text { tkm] }}\end{array}$} & \multirow{2}{*}{$\begin{array}{c}\text { Prepravný } \\
\text { výkon } \\
\text { [tkm] * }\end{array}$} & \multirow{2}{*}{ Poznámka } \\
\hline & & $\begin{array}{c}\text { Absolútna } \\
{[€]}\end{array}$ & $\begin{array}{c}\text { Jednotková } \\
{[€ / \mathbf{k m}]}\end{array}$ & & & \\
\hline \multirow{3}{*}{$\begin{array}{c}\text { KE } \\
\text { nákladná } \\
\text { - BA } \\
\text { východ } \\
\text { severná } \\
\text { trasa }\end{array}$} & \multirow{3}{*}{454,34} & 94,17 & 0,21 & 0,00864 & \multirow{3}{*}{10904,16} & $\begin{array}{l}\text { pravidelná, } \\
\text { zl'ava pre }\end{array}$ \\
\hline & & & & & & Nex a Pn \\
\hline & & 73,29 & 0,16 & 0,00672 & & $\begin{array}{l}\text { príležitostná } \\
\text { bez zl'avy }\end{array}$ \\
\hline \multirow{2}{*}{$\begin{array}{c}\text { BA } \\
\text { východ - } \\
\text { ZV nákl. - } \\
\text { KE nákl. }\end{array}$} & \multirow[t]{2}{*}{397,34} & 77,7 & 0,20 & 0,00815 & \multirow[t]{2}{*}{9536,16} & $\begin{array}{l}\text { pravidelná, } \\
\text { zl'ava pre } \\
\text { Nex a Pn }\end{array}$ \\
\hline & & 60,37 & 0,15 & 0,00633 & & $\begin{array}{c}\text { príležitostná } \\
\text { bez zl'avy }\end{array}$ \\
\hline \multirow{2}{*}{$\begin{array}{c}\text { ZV } \\
\text { východ - } \\
\text { BB - ZA } \\
\text { Teplička }\end{array}$} & \multirow[t]{2}{*}{144,83} & 13,2 & 0,09 & 0,00380 & \multirow[t]{2}{*}{3475,92} & $\begin{array}{c}\text { pravidelná, } \\
\text { zl'ava pre } \\
\text { Nex a Pn }\end{array}$ \\
\hline & & 10,24 & 0,07 & 0,00295 & & $\begin{array}{c}\text { príležitostná } \\
\text { bez zl'avy }\end{array}$ \\
\hline \multirow{3}{*}{$\begin{array}{c}\text { Nit. } \\
\text { Pravno - } \\
\text { Komárno }\end{array}$} & \multirow{3}{*}{174,06} & 13,88 & 0,08 & 0,00332 & \multirow{3}{*}{4177,44} & $\begin{array}{l}\text { pravidelná, } \\
\text { zl'ava pre }\end{array}$ \\
\hline & & & & & & Nex a Pn \\
\hline & & 10,74 & 0,06 & 0,00257 & & $\begin{array}{c}\text { príležitostná } \\
\text { bez zl'avy }\end{array}$ \\
\hline
\end{tabular}

*užitočná hmotnost' súpravy 24 ton

\section{Trasa Košice - Bratislava}

Prvá analyzovaná je trasa z Košíc, konkrétne z vlakovej stanice Košice nákladná stanica do vlakovej stanice Bratislava východ. Trasa je vedená severne, cez mestá Liptovský Mikuláš, Žilina a Trnava. Vzdialenost' týchto staníc železničnou dopravou je 444,07 km, cestnou dopravou 454,34 km. Podl'a plánu vlakotvorby nákladnej dopravy je dížka súpravy na tejto trase $615 \mathrm{~m}$ a pravidelná hmotnost' súpravy je 2200 ton. Z týchto údajov bol následne vyjadrený počet vozňov pre modelový vlak; 25, s úžitkovou hmotnost'ou 1587,5 tony. Následne bol vyjadrený prepravný výkon na ktorého základe boli vyjadrené jednotkové náklady v $€ /$ tkm. Obdobný princíp bol použitý pri výpočte nákladov pre cestnú nákladnú dopravu. Pre účely výpočtu bolo použité vozidlo nad 12 ton celkovej hmotnosti s 5 nápravami a užitočnou hmotnost'ou 24 ton. Jednotlivé náklady sú uvedené v tabul'ke 1 a 2. Cenová diferencia medzi najnižšou sadzbou cestnej nákladnej dopravy a najvyššou sadzbou železničnej nákladnej dopravy je na úrovni 85,45 \%. Cenová diferencia medzi najvyššou sadzbou cestnej nákladnej dopravy a najnižšou sadzbou železničnej nákladnej dopravy je na úrovni 93,63 \%. Rozdiel v maximálnej a minimálnej možnej sadzbe v cestnej nákladnej doprave predstavuje 0,00252 €/tkm. Rozdiel v maximálnej a minimálnej možnej sadzbe v železničnej nákladnej doprave predstavuje 0,00034€/tkm. 


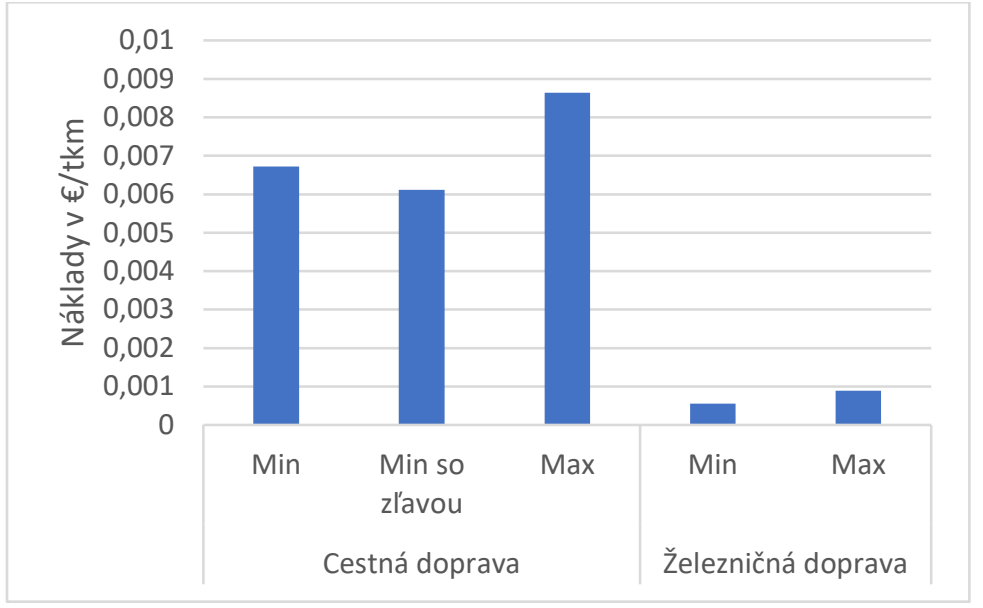

Obr. 1 - Grafické znázornenie výšky nákladov pre trasu Košice - Bratislava; Zdroj: autori

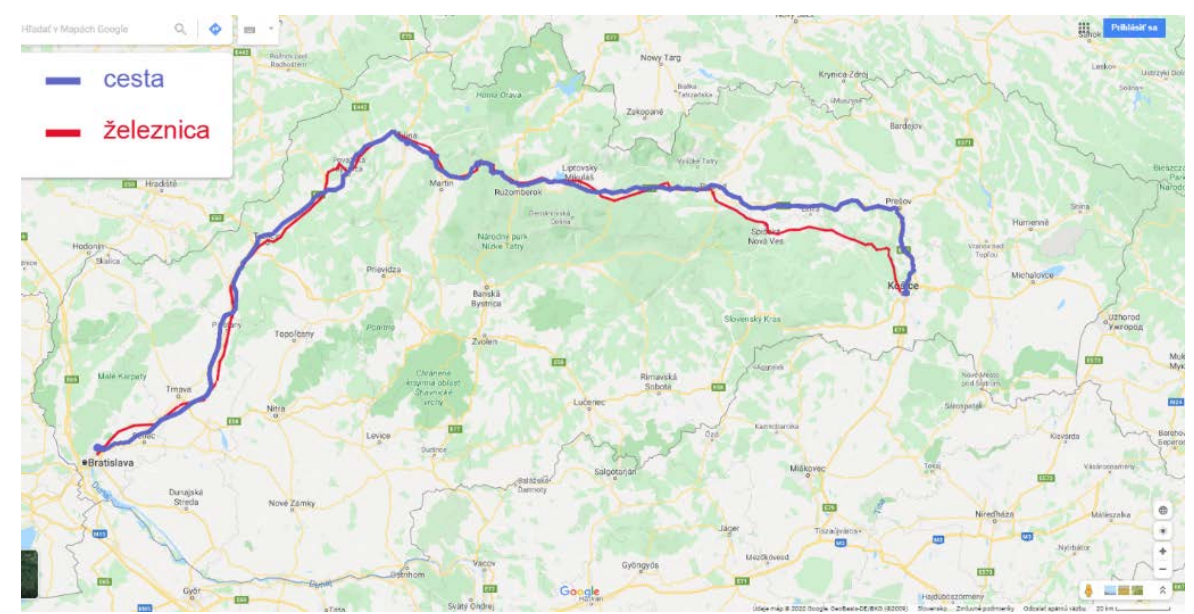

Obr. 2 - Grafické znázornenie trasy cestnej a železničnej dopravy na trase Košice - Bratislava; Zdroj: autori na základe googlemaps

\section{Trasa Bratislava - Zvolen - Košice}

Ďalšia trasa v analýze je trasa z Bratislavy do Košíc avšak v porovnaní s prvou analyzovanou trasou je táto trasa vedená južne cez mesto Zvolen, konkrétne zo stanice Bratislava východ sever cez stanicu Zvolen nákladná stanica a trasa končí v stanici Košice nákladná stanica. Vzdialenost' týchto staníc železničnou dopravou je $428,72 \mathrm{~km}$, cestnou dopravou $397,34 \mathrm{~km}$. Dížka súpravy na tejto trase podla plánu vlakotvorby nákladnej dopravy je $510 \mathrm{~m}$ a pravidelná hmotnost' súpravy je 1400 ton. Z týchto údajov bol následne vyjadrený počet vozňov pre modelový vlak; 21, s úžitkovou hmotnost'ou 1333,5 tony. Následne bol vyjadrený prepravný výkon na ktorého základe boli vyjadrené jednotkové náklady v €/tkm. Cenová diferencia medzi najnižšou sadzbou cestnej nákladnej dopravy a najvyššou sadzbou železničnej nákladnej dopravy je na úrovni 82,29 \%. Cenová diferencia medzi najvyššou sadzbou cestnej nákladnej dopravy a najnižšou sadzbou železničnej nákladnej dopravy je na úrovni 92,27 \%. Rozdiel v maximálnej a minimálnej možnej sadzbe $\mathrm{v}$ cestnej nákladnej doprave predstavuje 0,00239 €/tkm. Rozdiel v maximálnej a minimálnej možnej sadzbe v železničnej nákladnej doprave predstavuje 0,00039€/tkm. 


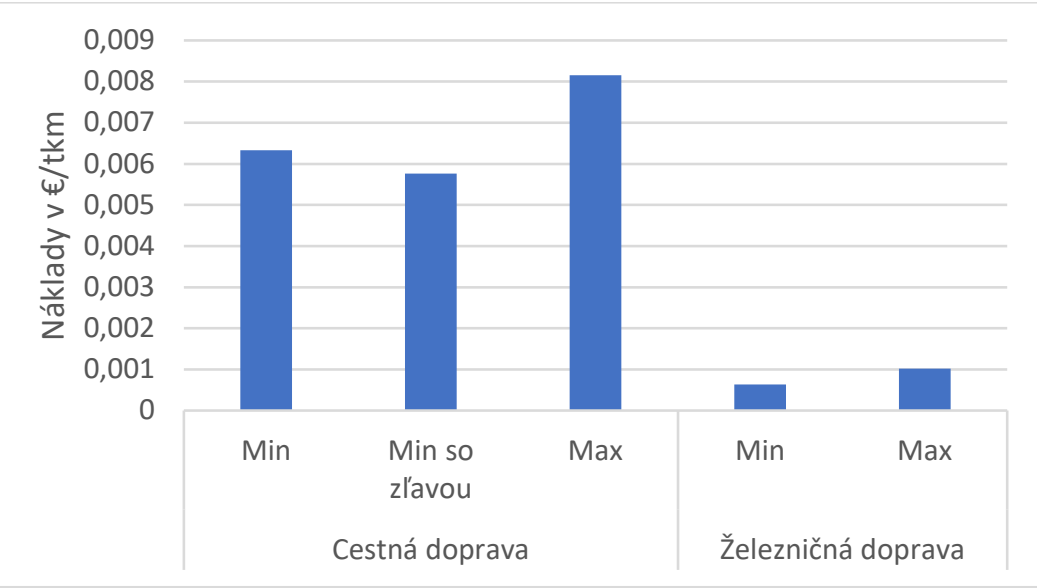

Obr. 3 - Grafické znázornenie výšky nákladov pre trasu Bratislava - Zvolen - Košice; Zdroj: autori na základe googlemaps

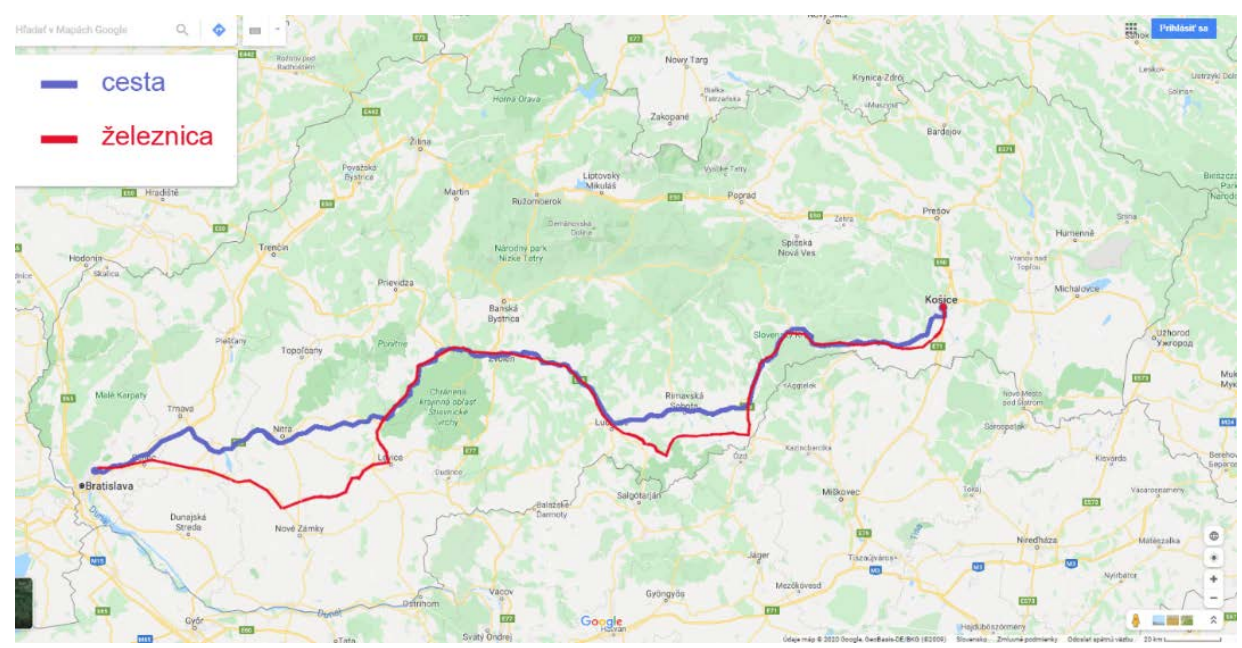

Obr. 4 - Grafické znázornenie trasy cestnej a železničnej dopravy na trase Bratislava - Zvolen - Košice; Zdroj: autori na základe googlemaps

\section{Trasa Zvolen - Banská Bystrica - Žilina-Teplička}

Tretia analyzovaná trasa začína v stanici Zvolen nákladná stanica, pokračuje stanicou Banská Bystrica a končí v stanici Žilina-Teplička. Vzdialenost' týchto staníc železničnou dopravou je 112,67 km, cestnou dopravou 144,83 km. Dížka súpravy na tejto trase podl'a plánu vlakotvorby nákladnej dopravy je $465 \mathrm{~m}$ a pravidelná hmotnost' súpravy je 1350 ton. Z týchto údajov bol následne vyjadrený počet vozňov pre modelový vlak; 18, s úžitkovou hmotnost'ou 1143 ton. Následne bol vyjadrený prepravný výkon na ktorého základe boli vyjadrené jednotkové náklady v €/tkm. Cenová diferencia medzi najnižšou sadzbou cestnej nákladnej dopravy a najvyššou sadzbou železničnej nákladnej dopravy je na úrovni 32,58 \%. Cenová diferencia medzi najvyššou sadzbou cestnej nákladnej dopravy a najnižšou sadzbou železničnej nákladnej dopravy je na úrovni 78,42 \%. Rozdiel v maximálnej a minimálnej možnej sadzbe v cestnej nákladnej doprave predstavuje 0,00112 €/tkm. Rozdiel v maximálnej a minimálnej možnej sadzbe $\mathrm{v}$ železničnej nákladnej doprave predstavuje 0,00099€/tkm. 


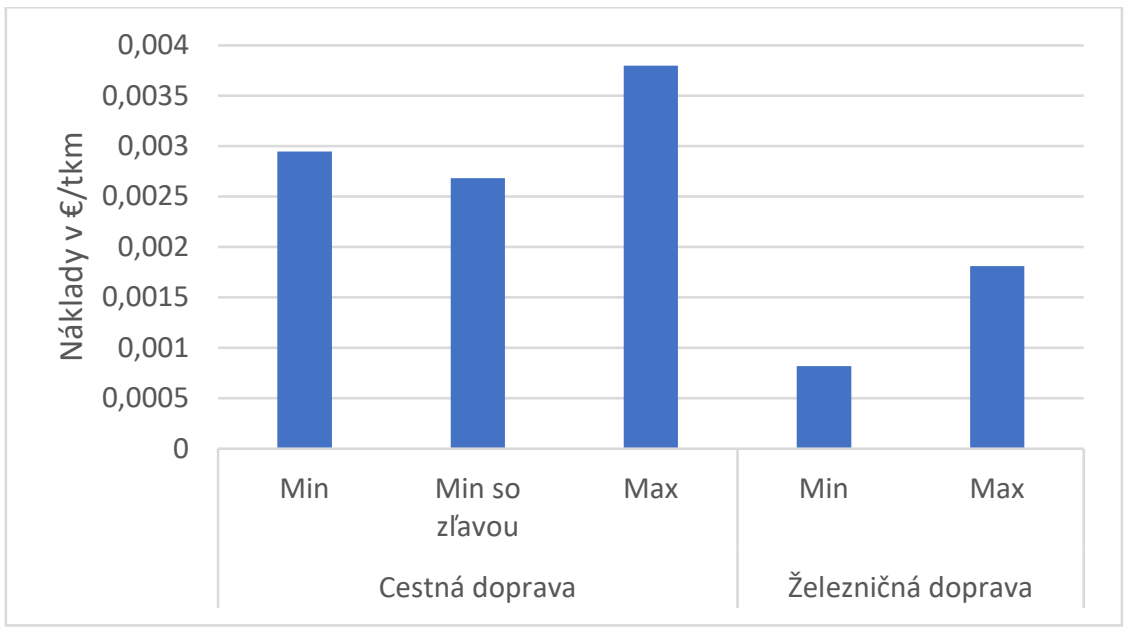

Obr. 5 - Grafické znázornenie výšky nákladov pre trasu Zvolen - Banská Bystrica - Žilina-Teplička; Zdroj: autori

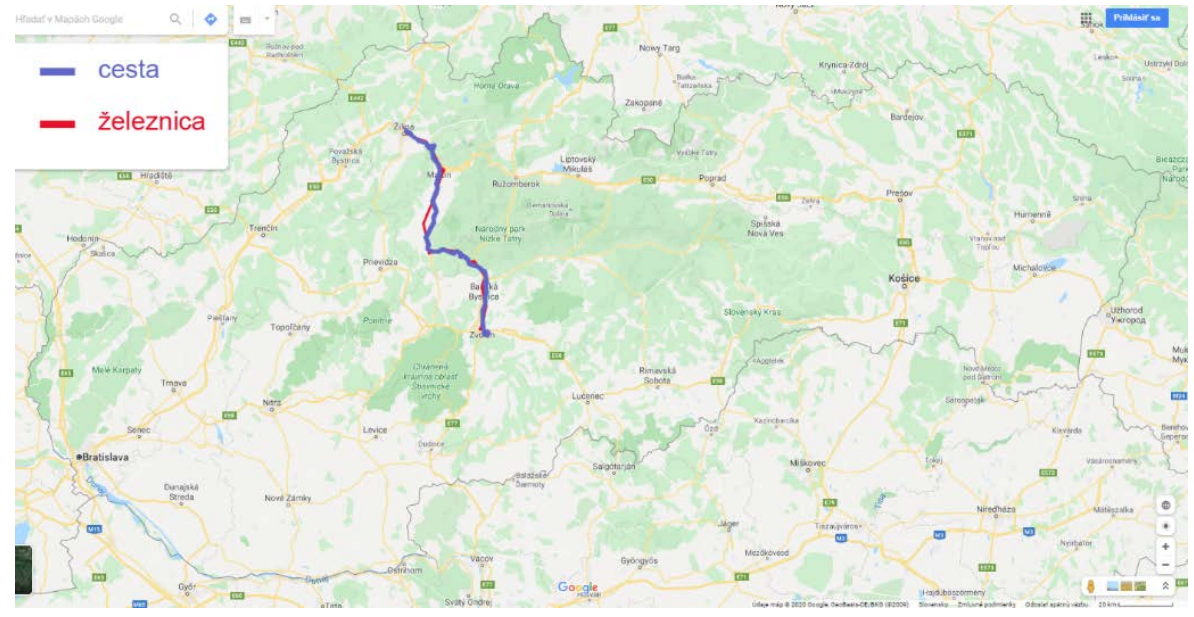

Obr. 6 - Grafické znázornenie trasy cestnej a železničnej dopravy na trase Zvolen - Banská Bystrica -ŽilinaTeplička; Zdroj: autori na základe googlemaps

\section{Trasa Nitrianske pravno - Komárno}

Poslednou analyzovanou trasou je trasa z Nitrianskeho Pravna do Komárna. Trasa prechádza cez mestá Šurany, Nitra a Topol'čany. Vzdialenost' týchto staníc železničnou dopravou je 154,09 km, cestnou dopravou 174,06 km. Dížka súpravy na tejto trase podl'a plánu vlakotvorby nákladnej dopravy je $500 \mathrm{~m}$ a pravidelná hmotnost' súpravy je 1400 ton. Z týchto údajov bol následne vyjadrený počet vozňov pre modelový vlak; 18, s úžitkovou hmotnost'ou 1143 ton. Následne bol vyjadrený prepravný výkon na ktorého základe boli vyjadrené jednotkové náklady v €/tkm. Cenová diferencia medzi najnižšou sadzbou cestnej nákladnej dopravy a najvyššou sadzbou železničnej nákladnej dopravy je na úrovni 53,82 \%. Cenová diferencia medzi najvyššou sadzbou cestnej nákladnej dopravy a najnižšou sadzbou železničnej nákladnej dopravy je na úrovni 78,61 \%. Rozdiel v maximálnej a minimálnej možnej sadzbe v cestnej nákladnej doprave predstavuje 0,00098 €/tkm. Rozdiel v maximálnej a minimálnej možnej sadzbe $\mathrm{v}$ železničnej nákladnej doprave predstavuje $0,00037 € /$ tkm. 


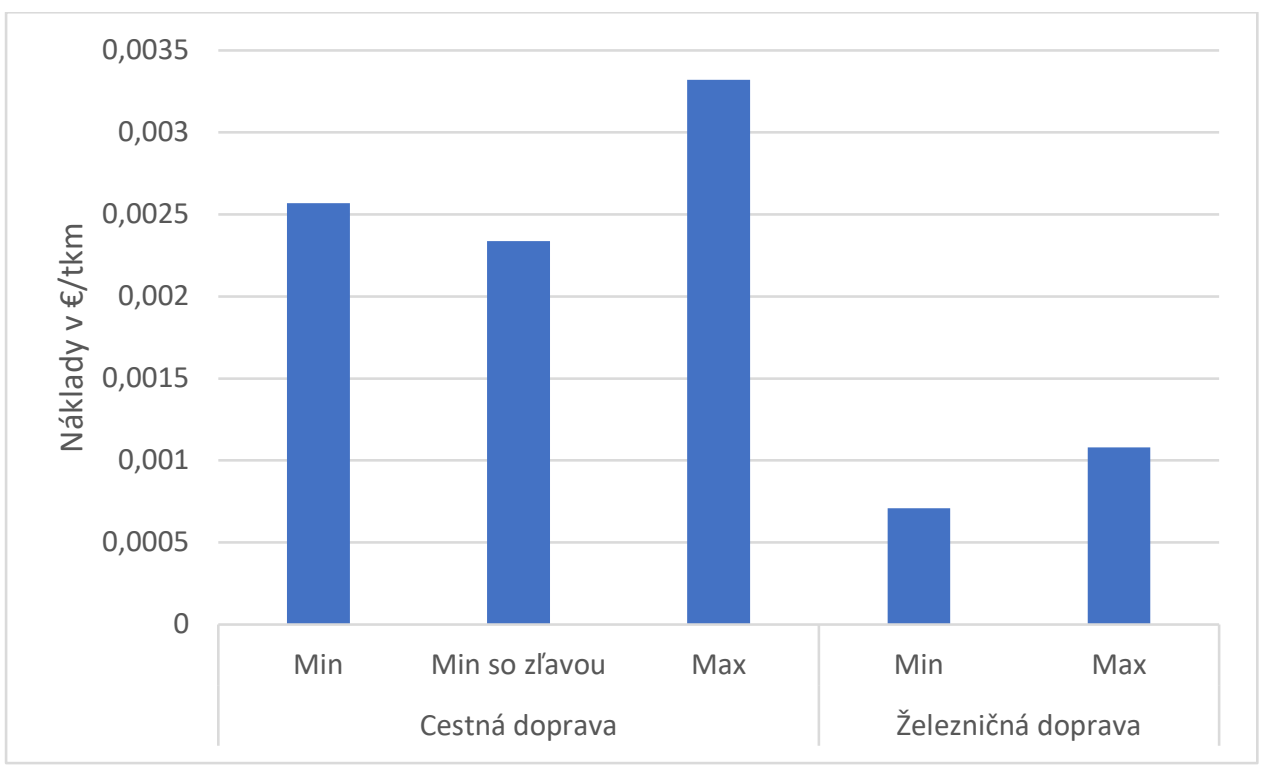

Obr. 7 - Grafické znázornenie výšky nákladov pre trasu Nitrianske Pravno - Komárno; Zdroj: autori

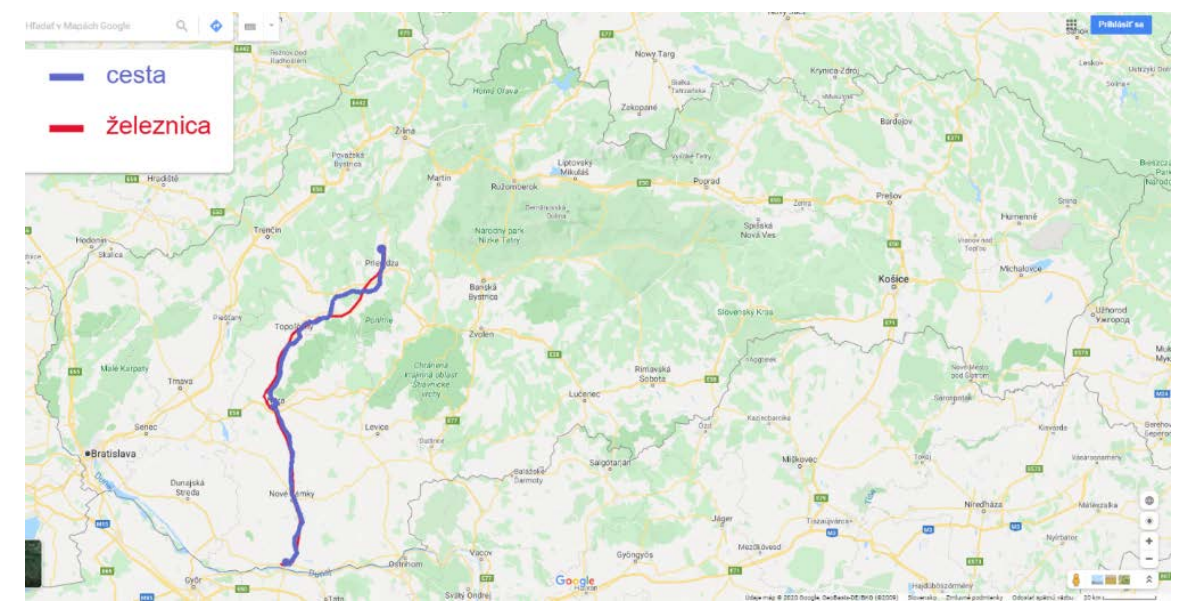

Obr. 8 - Grafické znázornenie trasy cestnej a železničnej dopravy na trase Nitrianske Pravno - Komárno; Zdroj: autori na základe googlemaps

\section{ZÁVER}

Výstupom skúmania je zrejmé, že maximálne náklady spojené s prístupom na dopravnú siet', vyjadrené v tonokilometroch, $\mathrm{v}$ železničnej doprave $\mathrm{v}$ SR sú pod úrovňou minimálnych nákladov spojených $\mathrm{s}$ prístupom na dopravnú siet' v cestnej doprave.

Pri porovnávaných trasách (uvedené v texte), priemerná cenová diferencia nadobúda hodnoty 66,8 \%, tzn., že náklady spojené s prístupom na cestnú infraštruktúru sú v porovnaní s nákladmi spojenými s prístupom na železničnú infraštruktúru priemerne o $2 / 3$ vyššie.

Pri porovnaní maximálnej výšky nákladov spojených s prístupom na cestnú infraštruktúru a minimálnych nákladov spojených s prístupom na železničnú infraštruktúru autori konštatujú výraznú diferenciu na úrovni 85,7 \%, čo znamená, že náklady spojené s prístupom na železničnú infraštruktúru predstavujú v priemere iba 14,3 \% nákladov spojených s prístupom na cestnú infraštruktúru.

Pri porovnaní maximálnych a minimálnych nákladov spojených s prístupom na infraštruktúru v cestnej doprave sa rozdiel medzi týmito hodnotami pohybuje $\mathrm{v}$ priemere na úrovni viac ako $0,001 € /$ tkm avšak pri výpočte nákladov je ovplyvňujúcim faktorom emisná trieda, ktorá je v priamej súvislosti s vekom motorového vozidla (jeden faktor) používaného pri preprave. 
Pri porovnaní maximálnych a minimálnych nákladov spojených $\mathrm{s}$ prístupom na infraštruktúru $\mathrm{v}$ železničnej doprave sa rozdiel medzi týmito hodnotami pohybuje v priemere na úrovni viac ako 0,0005 $€ /$ tkm avšak do výpočtu nákladov vstupujú viaceré faktory, ktorými sú:

- pravidelnost' trasy tzn. či je daná trasa zapísaná v GVD alebo je príležitostná (ad-hoc),

- cenová diferenciácia na základe vzdialenosti tzn. čím dlhšia je trasa prepravy, tým nižšia je cena na vlakokilometer,

- možná výška poskytnutej zl'avy manažérom infraštruktúry tzn. výška zl'avy poskytovaná ŽSR pre rôzne druhy vlakov (Nex, Pn, Mn, Vleč).

$\mathrm{V}$ praxi to znamená, že $\mathrm{v}$ cestnej nákladnej doprave je rozhodujúcim faktorom výber konkrétneho dopravcu s konkrétnym vozidlovým parkom, pričom $v$ železničnej doprave $\mathrm{z}$ hladiska ceny nie je výber železničného dopravcu až tak rozhodujúci ako v cestnej doprave nakol'ko do výslednej ceny prístupu na infraštruktúru vstupuje viacero faktorov. Príspevok nevyčerpal všetky aspekty danej problematiky, ale naznačil ako je potrebné postupovat’ pri porovnávaní nákladov na použitie dopravnej infraštruktúry na podobných trasách v cestnej nákladnej a železničnej doprave. Nie je možné zjednodušit' kalkuláciu nákladov za použitie dopravnej infraštruktúry napr. cez percentuálny paušálny príplatok.

Rozhodovanie o použití konkrétneho druhu dopravy závisí od celého radu faktorov, nie len od poplatkov za prístup na dopravnú cestu, ale napríklad aj viacerými obmedzeniami cestnej nákladnej dopravy napríklad aj nedostatku vodičov (Kleprlík et al. 2019).

\section{Pod'akovanie}

Tento príspevok vznikol vd’aka podpore v rámci operačného programu Výskum a vývoj pre projekt: Centrum excelentnosti pre systémy a služby inteligentnej dopravy II., ITMS 26220120050 spolufinancovaný zo zdrojov Európskeho fondu regionálneho rozvoja a projektu inštitucionálného výskumu Fakulty PEDAS č. 7/PEDAS/2019..

\section{Literatura}

Európska Komisia. 2011. Biela kniha - Plán jednotného európskeho dopravného priestoru - Vytvorenie konkurencieschopného dopravnému systému efektívne využívajúceho zdroje. Brusel.

Gnap, J., Poliak, M., Semanova, S. 2019. The issue of a transport mode choice from the perspective of enterprise logistics. Open Engineering, 9(1), s. 374-383. doi:10.1515/eng-2019-0044,

Huber, T., Grossner, T., Vdi. 2017. Future $\mathrm{CO}_{2}$ legislation and innovations to reduce TCO - using Continental Innovation Truck as an example. Commercial Vehicles 2017: Truck, Bus, Van, Trailer, 2298, s. 79-102.

Jost, F. 2017. Infrastructure Charges for International Train Services, Review of Network Economics, 16(2), s. 171-176.

Kleprlík, J., Talácko, V. 2019. Možnosti řešení nedostatečného počtu profesionálních řidičů (Possibilities How to Solve the Insufficient Number of Professional Drivers). Perner's Contacts. 14(1), s. 81 - 93.

Lee, S. 2018. Transport policies, induced traffic and their influence od vehicle emissions in developed and developing countries, Energy Policy 121, s. 264-274

Odolinski, K., Boysen, H. E. 2019. Railway line capacity utilisation and its impact on maintenance costs, Journal of Rail Transport Planning \& Management, 9, s. 22-33.

Poliak, M., Hammer, J. et. al. 2018. The impact of the transport route on the cost of the transfer, Conference: 11th International Scientific and Technical Conference on Automotive Safety, IEEE, 2018, <doi: 10.1109/AUTOSAFE.2018.8373319>. 
Skrúcaný, T., Kendra, M., Kalina, T., Jurkovič, M., Vojtek, M., Synák, F. 2018. Environmental comparison of different transport mode. Nase More, 65 (4), s. 192-196. <doi:10.17818/NM/2018/4SI.5>.

Stopka, O., Chovancova, M., Kampf, R. (2017). Proposal for Streamlining the Railway Infrastructure Capacity on the Specific Track Section in the Context of Establishing an Integrated Transport System, 18th International Scientific Conference on LOGI, 134, 00055, <doi: 10.1051/matecconf/201713400055>.

Zgonc, B., Tekavčič, M., Jakšič, M. 2019. The impact of distance on mode choice in freight transport. European Transport Research Review, 11(10), <doi:10.1186/s12544-019-0346-8>. 